\title{
Ventricular tachycardia in a patient with toxoplasmosis
}

\author{
A. S. Mary ${ }^{1}$ and M. Hamilton \\ From Chelmsford and Essex Hospital
}

A patient with dysrhythmia and serological evidence of toxoplasmosis is described. Paroxysmal ventricular tachycardia is reported for the first time in this condition; it was possibly benefited by specific therapy.

Toxoplasmosa gondii was first reported to cause toxoplasmosis with myocardial involvement in adults by Pinkerton and Henderson in 194I. Since then, many reports of myocardial involvement, either during acute generalized toxoplasmosis (Bengtsson, 1950; Wertlake and Winter, 1965; Menon and Simpson, 1966) or as the prominent feature of the disease (Kass et al., 1952; Paulley et al., 1954; Potts and Williams, 1956; Hakkila, Frick, and Halonen, 1958; Niedmann et al., I962; Adams, 1962; Reid, 1962; Ward et al., 1964; Durgé, Baqai, and Ward, 1967; Harvey, McLeod, and Turtle, 1966; Shee, I964; Mullan, Henry, and Beverley, I968; Arribada and Escobar, 1968) have been noted. Lymphadenopathy is the commonest adult manifestation of toxoplasmosis (Beattie, 1958).

The diagnosis of toxoplasma myocarditis during life is difficult and must rest on a compatible clinical picture, exclusion of other causes of similar illness, and evidence of toxoplasma infection by the demonstration of $T$. gondii in accessible tissue or by positive serological tests (Cathie, I955a; Beattie, 1958; Jacobs, 1962).

We describe here a patient with suspicious serological evidence of toxoplasmosis and a myocardial lesion, the latter manifesting as paroxysmal ventricular tachycardia and syncopal attacks.

\section{History}

A 45-year-old tree-feller, from Maldon, Essex, was found to have runs of ventricular ectopic beats during admission for removal of the right submaxillary gland due to calculus obstruction in February 1969 (Fig.).

\footnotetext{
1 Present address: Department of Cardio-thoracic Surgety, Leeds General Infirmary, Great George Street, Leeds I.
}

Since June 1968, he had experienced attacks of mild left-sided chest pains, worse on inspiration. The pain did not prevent his working until June 1969, when it became worse and associated with dyspnoea on exertion. He was afebrile, and a transient left basal lung shadow was found on chest $x$-ray. A course of ampicillin did not relieve his pain or his dyspnoea. He was then referred to the outpatient clinic, where alternate ventricular ectopic beats were discovered in his electrocardiogram at a time when he complained of palpitation. These were not relieved by procainamide $250 \mathrm{mg}$ 6-hourly.

In October 1969, he was admitted to the Chelmsford and Essex Hospital because of persistent palpitations, headache, syncopal attacks, and vague abdominal pains. His blood pressure was $140 / 80 \mathrm{mmHg}$. The only abnormal physical findings comprised xanthelasma on the upper eyelids, alternate ventricular ectopic beats, and a liver palpable two fingers breadth below the costal margin. There was no clinical, radiographic, or cardiographic evidence of ventricular hypertrophy. Lung $x$-ray and FVC and FEV 1 were normal. Blood counts, erythrocyte sedimentation rate, blood urea and electrolytes, transaminases, protein electrophoresis, cholesterol, glucose, antistreptolysin titre, liver function tests, liver biopsy, and protein-bound iodine were all normal. Urine and blood culture were sterile. Wassermann and Kahn tests, agglutination tests for salmonella and brucella, and the Paul-Bunnell test were negative. No lupus erythematosus cells were detected in his blood. Urinary excretion of 5-hydroxy-3-indole acetic acid and vanylyl mandelic acid were within normal limits. Skeletal $x$-ray survey was normal. The toxoplasma dye test titre in October 1969 was $\mathrm{r} / \mathrm{ro24}$. Procainamide $500 \mathrm{mg} 6$-hourly abolished the ectopic beats and when discharged he had lost his symptoms.

The patient remained well until towards the end of November 1969, when he was readmitted after several attacks of loss of consciousness, during one of which his pulse rate was reported by his general practitioner to be 30 a minute, and during that attack his recovery coincided with the return of his normal heart rate. On 


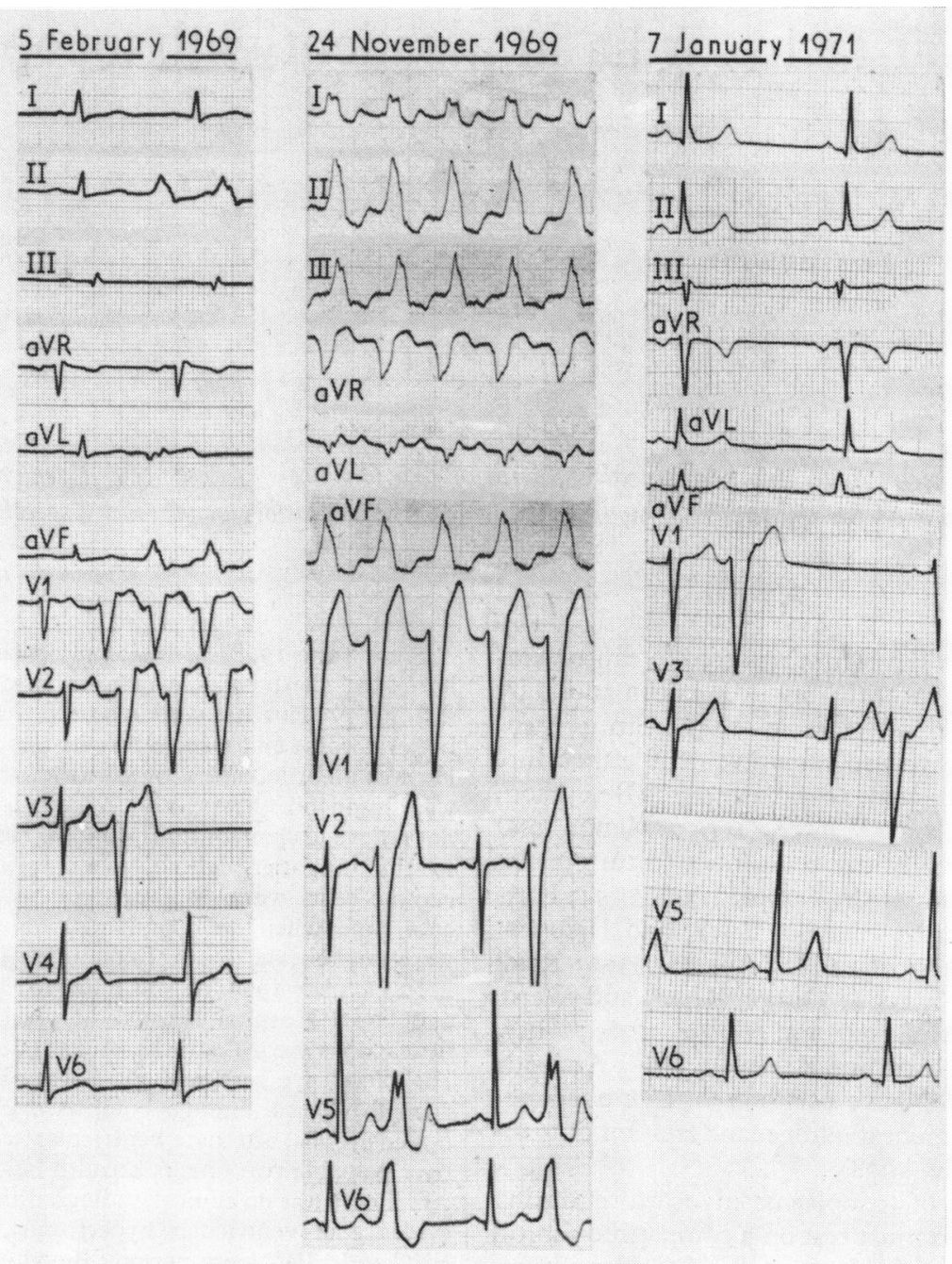

FIG. Electrocardiograms recorded on 5 February 1969 during an admission for submaxillary gland surgery, on 24 November 1969 after an admission for repeated episodes of loss of consciousness, and on the 7 Fanuary 1971, one year after a course of pyrimethamine and sulphadiazine therapy.

admission his jugular venous pressure was raised $(5 \mathrm{~cm})$ and his heart rate was approximately 160 a minute. The rhythm on electrocardiogram was paroxysmal ventricular tachycardia (Fig.). This was not affected by lignocaine $75 \mathrm{mg}$ intravenously, but responded to procainamide, later combined with sodium phenytoin therapy $100 \mathrm{mg}$ t.d.s. The cardiac failure responded to diuretic therapy. Cerebrospinal fluid, obtained by lumbar puncture, and electroencephalography were normal. The toxoplasma dye test titre remained at I/1024. In December I969 he started treatment with pyrimethamine and sulphonamide (pyrimethamine $50 \mathrm{mg}$ initially, then $25 \mathrm{mg}$ a day for one month; and sulphadiazine I g 6-hourly for three months). The rhythm remained stable, and the toxoplasma dye test titre in February 1970 fell to $1 / 512$, but by then his cardiac failure necessitated the addition of spironolactone therapy.

In April I970 he was readmitted for recurrence of paroxysmal ventricular tachycardia and faintness. Propranolol $40 \mathrm{mg} 6$-hourly and procainamide $500 \mathrm{mg} \mathrm{3-}$ hourly abolished the tachycardia and he was maintained on diuretic therapy. The electroencephalogram and agglutination tests were repeated and were normal. The toxoplasma dye test titre was now only $1 / 256$. He has 
remained well since then, apart from occasional palpitation and slight dyspnoea (Fig.).

His father had suffered from ischaemic heart disease. His sister was well and her toxoplasma dye test titre was $I / 8$, his poodle dog, aged 4 years, had no significant illness, and its toxoplasma dye test titre was $1 / 32$.

\section{Discussion}

The reported patterns of myocardial involvement in toxoplasmosis take several forms. ST changes on electrocardiography (Adams, I962; Bengtsson, I950; Ström, 195I), transient QT prolongation (Kass et al., 1952), supraventricular tachycardia (Harvey et al., 1966; Wertlake and Winter, 1965), transitory paroxysmal nodal rhythm (Pinkerton and Henderson, 194I), atrial flutter (Ward et al., 1964), atrial fibrillation (Paulley et al., 1954; Hakkila et al., 1958; Ward et al., 1964; Menon and Simpson, 1966; Arribada and Escobar, 1968), ventricular ectopic beats (Menon and Simpson, 1966; Arribada and Escobar, 1968; Mullan et al., 1968), bundle-branch block (Potts and Williams, 1956; Arribada and Escobar, 1968), and heart block (Shee, 1964; Arribada and Escobar, 1968) have been described.

The usefulness and specificity of serological data have been investigated by Bakal (1964-1965) and Cathie and Dudgeon (1953). In the United Kingdom, however, these serological dye tests are positive in 40 to 50 per cent of the adult population (Beattie, 1958; Cathie and Dudgeon, 1953; Cathie, 1954), and complement-fixation tests in 7 to ro per cent (Cathie and Dudgeon, 1953; Cathie, 1954). The relation between the titre and clinical infection is difficult to define; Cathie isolated T. gondii by ani$\mathrm{mal}$ inoculation of a piece of myocardium from a patient who had suffered myocarditis and had a toxoplasma dye test of only $1 / 32$, and a complementfixation titre of only I/8 (Cathie, 1955b). It is difficult to time the onset of infection, though a rising titre, the presence of high titres with a suggestive clinical picture, or the exclusion of other causes, is of help (Beattie, 1958; Cathie and Dudgeon, 1953).

We believe our patient suffered toxoplasmosis because of his high dye test titre. His cardiac manifestation could be due to ischaemic heart disease, though this was not suggested by cardiac pain, by specific ischaemic electrocardiographic changes, or by raised serum transaminase levels. Proof of cardiac involvement by toxoplasmosis during life is obviously difficult. Cysts alone (Mantz, Dailey, and Grocott, 1949; Reid, 1962; Kean and Grocott, 1945), or mild inflammatory reaction with large colonies of organisms (Pinkerton and Henderson, 194I), have been found in the myocardium with no obvious clinical evidence of heart disease. Jacobs
(1962) suggested that, though a cyst per se might be harmless in the myocardium, its rupture and consequent hypersensitivity reaction could contribute to inflammation in the myocardium and to the clinical picture. Myocarditis due to toxoplasmosis has been confirmed at necropsy in several instances (Pinkerton and Henderson, I94I; Kass et al., 1952; Potts and Williams, 1956; Vukasovic et al., 1963; Durgé et al., 1967; Wertlake and Winter, 1965; Arribada and Escobar, 1968).

The response to specific therapy is variable. During the early stages the proliferating organism is relatively sensitive; the cyst form, however, is difficult to eradicate, and on rupture may activate the disease, possibly provoking a hypersensitive reaction, as already mentioned. Specific therapy is not expected to benefit chronic myocardial damage. However, 8 out of II patients with toxoplasma myocarditis benefited from treatment by pyrimethamine, sulphadiazine, and prednisone (Arribada and Escobar, 1968), as did one patient with Adams-Stokes attacks due to toxoplasma myocarditis (Shee, 1964), and 3 patients suffering, respectively, from acute febrile illness, lymphadenopathy with ST abnormalities on the cardiogram, atrial flutter with heart failure, and myocarditis with pericarditis, lymphadenopathy, and pleurisy after meningoencephalitis treated with sulphonamide and pyrimethamine (Adams, 1962; Durgé et al., 1967; Hakkila et al., I958).

The recurrence of tachycardia without a rise of dye test titre in our patient could have been due to residual myocardial damage. Jacobs (1962) suggested that cysts incompletely eliminated were capable of further multiplication or rupture, inducing local inflammation.

In cardiac involvement, failure to respond to specific therapy is reported (Mullen et al., 1968; Harvey et al., 1966). Arribada and Escobar (1968) reported 2 patients who died of cardiac deterioration, despite specific therapy; both had extensive fibrosis of the myocardium. Another patient who partially recovered and then relapsed was described by Harvey et al. (1966); the myocardium showed thinning of muscle fibres, with interstitial fibrosis and oedema.

In view of the exclusion of other causes of myocarditis and the response, albeit incomplete, to specific therapy, we believe that our patient had suffered toxoplasma myocarditis, possibly leaving an active residual myocardial lesion together with paroxysmal ventricular tachycardia (which hitherto has not been reported). Serial serological tests and biopsy of accessible involved tissue for toxoplasma infection are warranted in view of the clinical improvement from early therapy. 


\section{References}

Adams, J. L. (1962). Acute toxoplasmosis with involvement of the heart. New Zealand Medical fournal, 61, 20.

Arribada, A., and Escobar, E. (1968). Cardiomyopathies produced by Toxoplasma gondii. American Heart fournal, 76, 329.

Bakal, P. M. (1964-1965). The specificity of Sabin and Feldman's dye test in the diagnosis of toxoplasmosis. Acta Leidensia Scholae Medicinae Tropicae, 33, 148.

Beattie, C. P. (1958). Toxoplasmosis, a general introduction. Transactions of the Ophthalmological Society of the United Kingdom, 78, 99.

Bengtsson, E. (I950). Herzaffektion bei Toxoplasmosis. Cardiologia, 17, 289.

Cathie, I. A. B. (1954). Toxoplasmosis in childhood. Lancet, I, 813 .

Cathie, I. A. B. (1955a). Laboratory diagnosis of toxoplasmosis. Lancet, $\mathbf{I}, 653$.

Cathie, I. A. B. (I955b). Myocardial toxoplasmosis. Lancet, I, 149 .

Cathie, I. A. B., and Dudgeon, J. A. (1953). The interpretation of tests for toxoplasmosis. Great Ormond Street fournal, 5,13 .

Durgé, N. G., Baqai, M. V., and Ward, R. (1967). Myocardial toxoplasmosis. Lancet 2, 155.

Hakkila, J., Frick, H. M., and Halonen, P. I. (1958). Pericarditis and myocarditis caused by toxoplasma; report of a case and review of the literature. American Heart fournal, $55,758$.

Harvey, H. P. B., McLeod, J. G., and Turtle, J. R. (1966). Myocarditis associated with toxoplasmosis. Australasian Annals of Medicine, 15, 169.

Jacobs, L. (1962). Toxoplasmosis. New Zealand Medical Fournal, 6r, 2.

Kass, E. H., Andrus, S. B., Adams, R. D., Turner, F. C., and Feldman, H. A. (1952). Toxoplasmosis in the human adult. Archives of Internal Medicine, 89, 759.

Kean, B. H., and Grocott, R. G. (1945). Sarcosporidiosis or toxoplasmosis in man and guinea-pig. American fournal of Pathology, 21, 467.

Mantz, F. A., Dailey, H. R., and Grocott, R. G. (1949). Toxoplasmosis in Panama; report of two additional cases. American fournal of Tropical Medicine, 29, 895.

Menon, I. S., and Simpson, J. (I966). Toxoplasmosis of liver and heart. British fournal of Clinical Practice, 20, $26 \mathrm{r}$.

Mullan, D. P., Henry, L., and Beverley, J. K. A. (1968). Toxoplasmosis and myocarditis. British Medical fournal, 4, 559.

Niedmann, G., del Campo, E., Thiermann, E., Sanchez, J., and Levy, M. (1962). Miocarditis de probable etiologia toxoplasmósica. Boletín Chileno de Parasitologia, 17, 58.

Paulley, J. W., Jones, R., Green, W. P. D., and Kane, E. P. (1954). Myocardial toxoplasmosis. Lancet, 2, 624 .

Pinkerton, H., and Henderson, R. G. (I94I). Adult toxoplasmosis. Fournal of the American Medical Association, 116, 807.

Potts, R. E., and Williams, A. A. (1956). Acute myocardial toxoplasmosis. Lancet, $\mathbf{r}, 483$.

Reid, J. D. (1962). Myocardial parasites; a report of two cases of probable toxoplasma infection. New Zealand Medical fournal, 6r, 9 .

Shee, J. C. (I964). Stokes-Adams attacks due to toxoplasma myocarditis. British Heart fournal, 26, 151 .

Ström, J. (I95I). Toxoplasmosis due to laboratory infection in two adults. Acta Medica Scandinavica, 139, 244.

Vukasovic, J., Arribada, A., Niedmann, G., and Thiermann, E. (1963). Myocardiopatía por toxoplasma gondii. Boletín Chileno de Parasitología, 18, 40.

Ward, R., Durgé, N. R., Arya, J., and Baqai, M. (1964). Myocardial toxoplasmosis. Lancet, 2, 723.

Wertlake, P. T., and Winter, T. S. (1965). Fatal toxoplasma myocarditis in an adult patient with acute lymphocytic leukemia. New England fournal of Medicine, 273, 438.

Requests for reprints to Dr. A. S. Mary, Department of Cardiothoracic Surgery, Leeds General Infirmary, Great George Street, Leeds I. 